\title{
Die bedreiging van die gemeente in Kolosse
}

\author{
JH Roberts \\ Universiteit van Suid-Afrika
}

\section{Abstract}

The threat to the church in Colossae

The variety of opinions on the matter of the Colossian error is illustrated by means of a brief overview of some of the most important contributions, taking into account a number of more recent discussions. The testimony of the text on the matters raised by the previous section is then discussed from the point of view of Colossians' distinctive textual form, as well as the stress on confessional material in the letter. Under this last heading the contents of the confessional pronouncement in 1: 13-20 is summarised, followed by a characterisation of what is now called the threat to the Christian community and which was found to be a Jewish mystical group outside of the community. In conclusion it is suggested that an interpretation along these lines can help to solve the problems of eschatology and Holy Spirit in Colossians.

Die ondersoek na die brief aan die Kolossense word tradisioneel toegespits op slegs enkele uitstaande gebiede waaroor daar blykbaar nog altyd vrae bestaan het. Afgesien van die vraagstuk van outeurskap, en dié van tyd en plek van ontstaan wat ten nouste daarmee saamhang, is dit veral die 'lied' in 1: 15-20, die vraag oor ' $n$ dwaalleer wat in die gemeente probleme sou gegee het, en die inhoud van bepaalde teologiese temas soos die Christologie en ekklesiologie wat die meeste aandag geniet het.

Wanneer die nuutste literatuur oor Kolossense bestudeer word, blyk dit spoedig dat hierdie velde van ondersoek nou aan mekaar verbind is en dat die een kwalik bespreek kan word sonder om die ander aan te sny. Een onderwerp staan in hierdie opsig besonderlik uit. Indien 'n mens jou op die hoogte wil stel oor die stand van die ondersoek na Kolossense, stuit jy teen die feit dat die vraag na die sogenaamde dwaalleer die ander vraagstukke vanself aantrek. Hierdie vraagstuk het immers te make, nie net met die vermanings wat die liggaam van die brief beslaan nie (Roberts 1988: 94-95), maar ook met die positiewe 
stelling van die skrywer se oortuigings soos dit in die briefopenings- en -oorgangsgedeeltes aan die lig tree. Dit kan dus vir die verstaan van die brief as geheel van besondere belang wees om 'n behoorlike greep te hê op die debat oor hierdie probleem.

\section{HOOGTEPUNTE IN DIE ONLANGSE NAVORSING}

Goeie oorsigte oor die stand van sake is beskikbaar in Francis en Meeks (1975) wat van die belangrikste bydraes herpubliseer met byvoeging van besonder insiggewende inleiding en epiloog; Schweizer (1976) wat die periode 1970-1976 dek; en Schenk (1987) wat die periode 1945-1985 dek; vergelyk ook Lähnemann (1971: 11-28); Bandstra (1974: 329-332); Evans (1982: 189-192).

In die nuwere ondersoek het daar 'n vraagteken ontstaan oor die gevestigde beskouing dat daar in die brief aan die Kolossense stryd gevoer word teen 'n dwaling wat in die gemeente sou posgevat het (Foerster 1966; Hooker 1973; Schenk 1987: 3350; vgl Schweizer 1976: 173-180; O'Brien 1982: xxxi). Dit word ook bevraagteken of ons hier met 'n kerklike of 'n buitekerklike stroming te doen het. Om dié redes behoort daar met omsigtigheid na 'n meer neutrale beskrywing as die gebruiklike 'dwaalleer' of 'kettery' ('heresy') gesoek te word - vandaar die aanduiding 'bedreiging' in die opskrif. Die keuse van so 'n neutrale beskrywing beveel hom des te meer aan wanneer in ag geneem word dat ook die wyse waarop die rigting aangespreek word en die aard van die bestryding daarvan, in die diskussie staan. Kan daar, met ander woorde, in die lig van die teksgegewens self, na dit wat hier gebeur met reg verwys word as 'n dwaalleer wat beveg word, of gaan dit veeleer om 'n waarskuwing teen 'n rigting wat vir die gemeente gevaar sou kon inhou indien dit navolging sou vind?

Alvorens op die saak self ingegaan word, kan dit waarde hê om (a) heel kortliks aandag te skenk aan die bydraes oor die afgelope eeu wat deur Francis en Meeks (1975) versamel is en (b) later die vraag te stel of hierdie bydraes enigsins ' $n$ ontwikkelingslyn vertoon, dit wil sê, of daar sprake is van vordering in die oplossing van die probleme. Die bedoeling met hierdie oorsig is egter nie om werklik die onderskeie studies volledig aan die orde te stel nie. Omdat hierdie versameling so belangrik is, is dit meermale in kleiner of groter omvang bespreek sodat dit nie hier herhaal hoef te word nie (vgl onder meer O'Brien 1982: xxxiii-xxxviii; vgl ook Francis \& Meeks 1975: 1-12; 209-218). 
Volgens Lightfoot ([1879] 1961: 73-113) is die dwaalleer van 'n Joods-gnostiese aard en Esseens van herkoms. Dit staan in lyn met die latere ontwikkelings wat by Sirillus aangetref word. Die gegewens in Kolossense sou hiervolgens klop met die drie hoofaspekte van die gnostisisme, te wete die intellektuele eksklusiwiteit (ons het die geheime kennis), die kosmogonie en teologie: Die bestaan van tussenwesens in die skeppingsproses (angellogie en Christologie), en die lewenspraktyk wat gekenmerk word deur die keuse tussen rigiede asketisme aan die een kant (so ten opsigte van die situasie in Kolossense) en ongebreidelde vryheid aan die ander.

Dibelius (1975: 61-121) se artikel wat uit 1917 dateer, wentel grotendeels om die interpretasie van embateúōn in Kolossense 2:18. Inskripsies uit die Apollo-tempel in Klaros vermeld dat afgesante wat die orakel kom raadpleeg het, in die misterie ingewy is en daarna 'ingegaan' het. Dibelius was van oordeel dat hierdie 'ingaan' verstaan moet word in die lig van die Isis-wyding wat deur Apuleius beskryf is, en dat dit te make het met die ingaan in die ruimte waar die gode-visies aanskou is. So ' $n$ misterie sou volgens hom ook in Kolosse as ' $n$ gnostiese kosmos-misterie bedryf gewees het en sou moes dien as agtergrond vir die verstaan van die gevaar wat die gemeente aldaar bedreig het. Lede van die Christelike gemeente sou kon meen dat inlywing in die misterie aan hulle 'n addisionele verskansing teen die elemente of magte kon bied (vgl veral bl 88-92).

Die bydrae van Bornkamm (1975: 123-145) dateer uit 1948. Soos die vorige twee bydraes word die gnostiese aard van die dwaling beklemtoon maar word die oorsprong daarvan in die Oosterse gnostiese spekulasies verlê, en word dit as 'n misterie-godsdiens verstaan wat hom in Joodse sinkretistiese kringe (van Ebionitiese of Elgasitiese inslag) ontplooi het en hom in die gemeente self gevestig het. Die posisie van Christus sou in gedrang gekom het deurdat Hy verstaan is as een van die ry van geestelike magte wat ' $n$ tussenposisie tussen die hemelse en die aardse wêreld sou ingeneem het: die volheid van God wat in Christus teenwoordig is, sou vir hulle juis op sy verhouding tot die elemente of magte gedui het aangesien laasgenoemde sy liggaam sou uitgemaak het, terwyl Christus die totaliteit van die wêreldelemente sou beslaan het (bl 128). Vir die ingewydes sou dit gegaan het om die opvaring na die ligwêreld deur die nakoming van die misteriekultus wat gekenmerk sou gewees het deur engeleverering, dit is verering van die elemente, en die misterie van hergeboorte wat as besnydenis beskryf sou gewees het. 
Die soeke na 'n wesenlike gnostiese agtergrond van die een of ander aard, word in die studie uit 1956 deur Lyonnet (1975: 147-161) van die hand gewys, alhoewel hy nog steeds na hulle as gnostici verwys. In 'n sekere mate keer hy terug na Lightfoot se opvatting oor 'n Esseense agtergrond, maar nou met die voordeel van die meestal pas gepubliseerde Qumraangeskrifte tot sy beskikking. Aan die een kant word die opvatting dat terme soos sōma en plērōma 'n gnostiese oorsprong sou hê, weerlê deur te wys op die stoïsynse agtergrond daarvan; andersyds word die tipiese uitdrukkings en opvattings van die teenstanders as van Joodse oorsprong bewys deur na veral parallelle uit Qumraan te verwys en aan te toon dat ons hier nie met gnostiese idees te make het nie.

Die eerste van Francis se twee artikels (Francis 1975a: 163-195) dateer uit 1963 . Hy begin deur te wys op die besondere moeilikhede waarvoor die teks die eksegeet stel: 'The interpretation of nearly every word or phrase has been disputed' (1975a: 163). Hierop volg 'n noukeurige bespreking van die problematiese uitdrukkings met die weergawe van die diverse standpunte wat ten opsigte van elkeen ingeneem word (bl 164-167). Dit lei hom tot die insig dat die sleutel tot die brief daarin lê dat uitsluitsel verkry word oor the meaning and interrelation of the terms humility, entering, and worship of angels. Insight into these questions should enable us to make some suggestions regarding the Colossian problem as a whole' (bl 167). Noukeurige ondersoek van 'n wye verskeidenheid toepaslike bronne (waaronder die Septuaginta, Filo en apokriewe geskrifte soos die Henogboeke, die Testamente van die twaalf Patriarge, Opvaart van Jesaja, die Barug-apokalipse, en ander Qumraangeskrifte), lei hom tot die oortuiging dat tapeinofrosūne en verwante vorms dui op vaste, asook ander rigoristiese praktyke waardeur gepoog is om visioene te beleef: 'Tertulian's exegesis of Daniel 10: $2 \mathrm{ff}$ is fully justified. Many similar examples where rigorist humility is effectual for visions are to be found in apocryphal literature' (bl 168). Dit op sy beurt staan in die nouste verband met die gedagte van die hemelreis en die ingaan in die hemel: 'Several of these Jewish-Christian writings specify that the consequence of this ascetic practice is entrance into the heavenly realm' (bl 168). En, alhoewel die werkwoord embateúo nie in hierdie verband in die bronne voorkom nie, is dit sonder meer duidelik dat dit die saak van toetrede tot die hemelse sfeer is wat hier aan die orde kom.

Hiermee word die vraag natuurlik dringend oor wat die sin van die belewenis is - ' $n$ vraag wat saamhang met 'what was seen upon 
entering', en waarop die antwoord lui: 'angelic worship' (bl 176). Dit gaan om die sien van die hemelse erediens - vergelyk Ascen Is 7: 13-9: 33, waarvan Francis sê: '... on his ascent, Isaiah sees the hosts of each of the seven heavens praise and glorify God' (bl 177). Dat dit hierby ook gaan om die deelname van die mistikus aan dié erediens, blyk uit talle plekke (Ascen Is 7: 37; 8: 17; 9: 28, 31, 33; T Job 48-50; 3 En 1: 12; Ap $\mathrm{Ab} 17$; T Isaac fo 16-17, vgl fo 15; 1 QSb 4,25-26; 1 QH 3,20-22; Corp Herm 1: 26). In al hierdie gevalle gaan dit om die diens (erediens) wat engele aan God bied, dit wil sê, diens van engele in die sin van diens deur engele verrig. Dit is Francis se siening dat thrēskeía tōn angéllōn in die lig van hierdie verwysings verstaan moet word. Dit impliseer dat die genitief in die uitdrukking teen die algemene opvatting in, maar tog met die steun van enkeles (soos Zahn 1906: 333-334; Ewald 1910: 395-398; Carr 1973: 499-450; Bandstra 1974: 331) as 'n genitivus subjectivus opgevat moet word. Bewys daarvoor dat thrēskeia inderdaad met daaropvolgende genitivus subjectivus voorkom, word in 4 Makkabeërs 5: 7 en in Josefus Antiquitatis 12, 253 gevind. Die fout van die teenstanders het dus nie op die vlak van die Christologie gelê, soos gewoonlik aangeneem word nie, en waarvolgens hulle 'the mediation or rule of powers other than Christ' voorgestaan het nie (bl 183). 'The pre-eminence of Christ over all powers was the pressupposition held in common by writer, readers, and errorists' (bl 183). Hulle werklike probleem het veeleer op die vlak van die soteriologie en die eskatologie gelê.

In sy tweede artikel in die bundel probeer Francis (1975b: 197-207) om die aanwending van embateúo in Kolossense nader te presiseer deur weer eens die agtergrondmateriaal deur te werk. Hy kom tot die konklusie: 'Having engaged in the preparatory discipline of humility, the Colossians sought to enter heaven in order to possess themselves of salvation, a portion in the Lord' (bl 199 - vgl Septuaginta Jos 19: 49, 51, asook EurHer, 863-878).

Op hierdie punt sou 'n mens graag wou probeer uitmaak of daar sprake van vordering in die ondersoek is, of daar ' $n$ bepaalde ontwikkelingslyn vasgestel kan word. Wanneer die nuwere werke in die lig van die bogaande oorsig gelees word, kan die volgende tog miskien, ondanks groot verskille in die interpretasie van detail, in hierdie verband aangestip word:

- 'n Sekere tendens kan waargeneem word wat dui op 'n wegbeweeg van die gnostiese interpretasie van die gegewens na die stel van 'n 
hoofsaaklik nie-gnostiese, maar wel sinkretistiese, Joodse agtergrond ter verklaring daarvan (Brandstra 1974: 339-343; Francis 1975a; 1975b; Schweizer 1976: 177-180; Evans 1982: 203-204; Bruce 1984: 201-204; Schenk 1987: 3349-3354; vgl ook Lähnemann 1971: 101; Gunther 1973; Yates 1986. Twee Suider-Afrikaanse bydraes gaan die koers van die gnostiek op: Groenewald 1944; Moyo 1984; vgl onder baie ander ook Stewart 1970).

- Die aard van die rigting wat teengestaan word, word in die lig van die bogaande hoofsaaklik gesoek in die rigting van die mistiek, veral die Joodse merkabah-mistiek (hieroor Scholem 1961: 40-79; Scholem 1971) wat gebaseer is op die gedagte van die sien van die hemelse strydwa en troon van God waarvoor die siel 'n hemelreis onderneem (Francis 1975a: 170; Bandstra 1974: 331-333; Bruce 1984: 201-204) en waarby die aanwending van vaste en ander streng dissiplinering van die liggaam die middels is wat tot die belewenis van die visioen lei. Hierteenoor word daar ook wel gedink aan 'n Joods-Pitagorese filosofiese rigting as agtergrond van die bedreiging (Schweizer 1976: 173-180).

- Onder die voorstanders van die hier gebode oplossingspogings word meestal nie daaraan getwyfel dat ons met 'n dwaling te doen het wat die gemeente binnegedring het nie. Dat enkele stemme hierteen opgegaan het, is aan die begin van hierdie oorsig aangestip. Hierdie insig moet met besondere erns bejeën word. Al het dit nie altyd die aandag gekry wat dit verdien nie, laat die teks self blyk dat die beste verklaring vir die gegewens gedien word deur die opvatting dat ons hier in die geheel nie met 'n kerlike dwaling te make het nie, maar wel met ' $n$ bedreiging van buite. In hierdie verband is die opmerkings deur Schenk (1987: 3349-3350) besonder insiggewend:

Aus einer Überbewertung von Kol 2 heraus wird meist die Frage einer "kolossischen Häresie" an die Anfang der Erörterungen gestellt, darin Anlas und Zweck gesehen und der Kol insgesamt als "eine programmatische antignostische Streitschrift" bestimmt. Nun hat sich shon vom Werkstil her gezeigt, dass textpragmatisch nicht von 'Polemik' gesprochen werden kann und die Art der den Christen insgesammt gegenübergestellten Warnsätze 1,23; 2,4.8.16.18 wie die abschliessende Folgerung 2,20 darauf hinweisen, dass es nicht um eine Bekämpfung einer 'Häresie' als solcher geht, sondern nur um die Immunisierung der christlichen Leser vor ihr. Das gibt der Position derer Recht, die in dem abgewehrten 
Phänomen eine nur von aussen (vgl auch 4,5) kommende Bedrohung sehen. Die Kategorien 'Häresie', '(juden-)christliche Irrlehre' sind hier dann nicht berechtigt.

- Teenoor die gnostiese interpretasie wat die kernpunt van die afwykende standpunt in 'n bedreiging op die vlak van die Christologie vind, kan Francis (1975a: 183-184), op grond van sy interpretasie van die diens van die engele, die klem na die soteriologie en eskatologie verlê (vgl ook Evans 1982: 203-204). Wie hom egter nie daarin volg dat ons hier met 'n binne-gemeentelike sekte te doen het nie, sal hierdie konklusie nie noodwendig vind nie: Die bedreiging sou beslis op al drie die terreine, en meer, 'n gevaar kon inhou (vgl ook Bandstra 1974: 343).

- Ten opsigte van die uitdrukking tā stoicheîa tố kósmou moet die aandag gevestig word op die besonder duidelike analise van Blinzler (1963) waaraan te min aandag gegee word (vgl verder Kehl 1967: 137-161; Kern 1974: 185-196). Hy gee 'n oorsig oor die betekenisse wat in die literatuur aan stoicheion toegedig is met afwysing van sekeres, wat wel populêr, maar onhoudbaar is, en dui aan dat die kombinasie tā stoicheîa tô̂ kósmou slegs aangewend word ten opsigte van die natuurelemente wat volgens antieke beskouing uit water, aarde, vuur en lug sou bestaan het. Paulus sou die uidrukking oordragtelik op die geestelike vlak aangewend het ter aanduiding van die nie-Christelike bestaanswyse. Schweizer (1976: 173-180) sluit hom by hierdie bevinding aan, maar neem die elemente van die wêreld letterlik op as die waardeur die siel (volgens die JoodsPitagorese agtergrond waarop hy hom stel) moes reis om die hemelse geweste te kon ingaan.

\section{DIE GETUIENIS VAN DIE TEKS}

In hierdie afdeling word beoog om die probleem te benader vanuit enersyds die eiesoortige gestruktureerdheid van die Kolossenseteks, andersyds vanuit die feitelike beklemtoning van belydenisaspekte in die teks, en ten slotte met verwysing na twee eienaardighede ten opsigte van Pauliniese teologie wat in die teks voorkom.

\subsection{Die eiesoortigheid van die teksvorm}

Die Pauliniese brief word daardeur gekenmerk dat bepaalde briefoorgange in die briefopeningsgedeeltes (vgl Roberts 1986) die briefliggaam 
vooruitloop, en dat laasgenoemde dan bestaan uit twee gedeeltes, te wete 'n teologies funderende gedeelte en 'n praktiese paranetiese gedeelte (White 1975: 53-54, 115,n28; vgl Roberts 1987: 29-30). In Kolossense is die briefoorgange oorvloediglik teenwoordig vanaf 1 : 13-2: 5 (Roberts 1986: 196). In die lig hiervan en van die gebruik in die ander briewe, sou 'n mens nou kon verwag dat ons by 2: 6 die aanvang van die teologiese gedeelte sou aantref. Anders as wat die meeste ' $n$ mens sou wil laat glo (vgl slegs, alle onderlinge variasie ten spyt, Lähnemann 1971; Ernst 1974; Lohse 1977; Gnilka 1980; Pokorny 1987), val die skrywer egter direk weg met die paranese (vgl hier ook Schenk 1987: 3348).

Hierdie waarneming is van veel groter gewig as wat miskien op die oog af mag blyk. Hier word naamlik geen tetiese bekamping van 'n dwaalleer in die gemeente gebied nie, en ook geen aanval op die voorstanders van die rigting wat afgewys word, geloots nie. Eerder word hier op vermanende wyse ' $n$ waarskuwing aan die lesers gerig om hulle nie te laat verlei deur bepaalde opvattings en praktyke van andere nie (vgl hier weer die aanhaling hierbo - afdeling 1 - van Schenk). Hieroor kon 2: 8 nie duideliker gewees het nie: Hulle moet oppas dat daar nie iemand sal kom (éstai $=$ fut) wat beheer oor hulle oorneem nie. Dat die skrywer negatief staan teenoor dié mens/mense blyk nie net uit die waarskuwing nie, maar ook uit uitdrukkings soos dià ... kenēs apátēs katà tēn parádosin tōn anthrōpōn (2: 8); há estin skià tōn mellóntōn (2: 17); eikē fusioúmenos hupò toû noòs tēs sarkòs autôิ (2: 18); ouk en timē tini pròs plèsmonèn tēs sarkós (2: 23). Tog val hy hulle nie aan nie en verwyt hy hulle nie afvalligheid nie - kennelik omdat hulle nie deel van die gemeente uitmaak nie en hulle standpunte en optredes nie 'n $\mathrm{d}$ waalleer in die gemeente verteenwoordig nie.

Dit mag voorkom of die uitdrukking tí hōs zōntes en kósmō dogmatízesthe (2: 20), teen hierdie siening stry. Maar die verklaring van dogmatizesthe (as mediaal of passief), in die sin van 'gehoorsaam wees aan ' $n$ verordening' (Bratcher \& Nida 1977: 70; Louw \& Nida 1988a: 468) hang saam met die ingewortelde opvatting in verband met 'n gemeentelike dwaling. Hierdie Nuwe-Testamentiese hapax legomenon kan ewe-goed as passief in 'n kousatiewe sin verstaan word: 'waarom laat julle vir julle voorskryf?' (vgl Zerwick \& Grosvenor 1979: 608: 'why do you let yourselves be dictated to?'; ook Gnilka 1980: 157). Nog beter kan die passief in sy gewone krag gehandhaaf word: 'waarom word daar nog aan julle reëls voorgeskryf (deur die opgeblasenes van buite) asof julle nog in die wêreld leef?' In die lig van die standpunt in die vorige 
paragraaf gestel, en binne die verband van die brief as geheel, is die implikasie hiervan: 'waarom word daar nog deur dié buitestaanders reëls aan julle opgedring?', met die verdere implikasie: 'waarom sou julle julle daaraan steur?' (vgl ook Hooker 1973: 317-318).

'n Tweede uitdrukking wat daarop sou kon dui dat die bedreiging wel die vorm van 'n binne-gemeentelike groep aangeneem het, is te vinde in 2: 19 - kaì ou kratōn tên kefalēn... Hieroor egter later meer.

Dit is duidelik dat die standpunt wat hier oor die briefvorm en die aard van die skrywer se optrede teenoor die bedreiging ingeneem is, die weg ooplaat vir ' $n$ oplossing van die vraag oor die aard van die bedreiging in die rigting van ' $n$ Joodse groep wat hulle vir die mistiese belewing van hemelreise geïnteresseer het. Maar hieroor later meer.

\subsection{Die beklemtoning van belydenisaspekte}

\subsubsection{Die belydenisinhoud}

Die belangrike rol wat belydenisaspekte in hierdie brief speel word wyd erken (vgl Roberts 1988: 91-95). Die funderende rol van die belydenisuitspraak in 1: 13-20, en die daaropvolgende uiteensetting in 1: 21-23 oor wat hierdie belydenis vir die lesers beteken, is deurslaggewend vir dit wat na die persoonlike verwysings as verdere oorgange (1: 24-2: 5) in die briefliggaam volg. Opsommenderwys word hier gestel:

- Heilshistories: God het die gelowiges gered sodat hulle in verbondenheid aan sy Seun verlossing, vergifnis het (1: 13-14).

- Die status van die Seun van God:

- Teenoor God: Hy is beeld van God (1: 15a).

- Teenoor die skepping: Hy is skeppingsmiddelaar, gaan aan die skepping vooraf, en neem die eerste plek in voor alle geskapene (1: 15b-17)

- Teenoor die kerk: Hy is Oorsprong van en Hoof oor die volk van God wat sy liggaam is; ook hier is $\mathrm{Hy}$ in alles die eerste (1: 18).

- God is volledig in die Seun teenwoordig en het deur sy sterwe aan die kruis die vyandige gebiede van hemel en aarde versoen (1: 19-20).

- Vir die gelowiges beteken dit dat ook hulle versoen is en met God in die regte verhouding gestel is deur sy sterwe - maar dan moet hulle bly vasstaan in die tradisie wat aan hulle as kérugma verkondig is en 
hulle nie laat weglei van die hoop wat dit vir hulle inhou nie (1: 21-23).

Soos gesê maak hierdie gedeelte deel uit van die oorgangsvorme in Kolossense en word die oorgange aangewend om voor te berei op en in te lei in die saak/sake waarop die outeur in sy brief wil ingaan. Ons sou dus kon verwag dat die vier punte hierbo genoem, ten minste ten dele (as 1: 15-20 nie die outeur se eie komposisie is nie), of selfs volledig, op die inhoud van die beskouing wat vir die gemeente ' $n$ bedreiging inhou, sal reflekteer.

\subsubsection{Karakterisering van die bedreiging}

Waarin was die bedreiging geleë? Formeel gesproke word dit in 2: 8 aangedui as filosofie (vgl ook 2: 23a), as leë dwaling (vgl ook 2: 4 goedklinkende argumente), en as oorlewering van mense (vgl ook 2: 22b), terwyl 2: 10 en 2: 15 laat sien dat ' $n$ bepaalde beskouing oor owerhede en magte ten dele die inhoud daarvan uitgemaak het. Verdere inhoudelike aanduidings word in 2: 16 en 2: 18 aangetref: Bepaalde voorskrifte oor ete en drinke, viering van feeste, nuwemaansgeleenthede en sabbatte, 'n strewe na nederigheid en die diens van engele. By die reeds gemelde aspekte voeg 2: 23 nog twee by: vrywillige godsdiens, en gestrenge dissipline van die liggaam, terwyl 2: 21 drie verbiedinge vermeld: Moenie vat nie, moenie proe nie, moenie aanraak nie. Hierby kom ten slotte nog die vermelding in 2: 18 dat die potensiële verleiers (enkelvoud staan hier tekenend van die groep) as mense wat die sake van nederigheid en engelediens waargeneem het toe hulle ingegaan het, ten onregte selfvoldaan is; asook in 2: 19 dat hulle nie aan die Hoof vashou nie.

In die aanduiding van hierdie rigting as filosofie het sommige daarvoor steun gevind dat hulle verteenwoordigend moes wees van 'n Grieks-filosofiese skool (Schweizer 1976: 176-180). Hierteenoor toon 2: 23 aan dat die begrip waarskynlik slegs dui op hulle beheptheid met dit wat hulle as wysheid beskou, maar dit nie is nie - wat inteendeel 'n $\mathrm{dwaling}$ sonder enige betekenis is, nikswerd, vol van goedklinkende maar valse argumente (2: 4,8 - en pithanalogia - vgl Louw \& Nida 1988a: 393; en dià ... kenès apátēs). Vir hulle gaan dit eger oor 'n saak van groot erns; hulle kan hulle naamlik op 'n bepaalde oorlewering beroep. Hiermee word ' $n$ beroep gedoen op vaste tradisiestof wat van oudsher af van die een na die ander oorgedra is en daarom groot gewig dra en met ' $n$ bepaalde waas van geheimsinnigheid omhul is omdat slegs die 
ingewydes met die inhoud daarvan vertroud is. Soos in die geval van die misteriegodsdienste is daar uiteraard wel enkele sake oor hulle bedrywighede bekend (die aspekte wat hier opgenoem word), maar bly die wesenlike van die tradisie in die duister gehul. En dit is juis hierdie verborge elemente wat daarvoor verantwoordelik is dat daar in soveel verskillende rigtings na die aard en oorsprong van die betrokke beweging gesoek word.

Uit die aanduidings op die inhoudelike vlak wat wel bekend is en hier vermeld is, staan twee uit as dié wat waarskynlik die mees kenmerkende aspek van die bedreiging saamvat, te wete hulle strewe na nederigheid en hulle gestrenge dissipline van die liggaam (2: $18 ; 2$ : 23). In 2: $23 \mathrm{kom}$ die twee gedagtes direk naas mekaar voor, in sommige handskrifte met kai verbind en in ander daarsonder. Die invoeging van die partikel is vanuit ' $n$ kopieerder se oogpunt makliker verklaarbaar om daardeur die drie dativi aan en te bind, as die weglating daarvan, en die lesing daarsonder word vroeg en wyd gesteun - onder andere deur $\mathrm{P}^{46}$ en Vaticanus (vgl die bespreking deur Metzger 1971: 624). In die lig hiervan behoort dit as latere invoeging behandel te word en is afeidia sōmatos bedoel as kwalifikasie by tapeinofrosúne. Die 'nederigheid' van die buitestaanders word hier dan gedefinieer in terme van asketiese praktyke (vgl Zerwick \& Grosvenor 1979: 609) en moes 'n tipiese eie-woord uit die geledere van hierdie groep gewees het. Dat dit die geval is, blyk ook later in die brief wanneer die skrywer die gemeentelede oproep tot ' $n$ lewe wat gekenmerk word deur nederigheid en wat hier kennelik op iets anders dui as in die geval van die groep se nederigheid (3: 12), asook deur die voorskryf van reëls deur die groep oor ete en drinke (2: 16), en die verbiedinge oor vat (seksueel?), proe en aanraak (2: 21). Al hierdie dinge wys onteenseglik op ' $n$ asketiese instelling en gebruike - iets wat nog verder versterk word deur (wat ongetwyfeld verdere reëls behels het oor) die tipiese Joodse (anders Lähnemann 1971: 83-89) viering van feeste, kalenderaangeleenthede (nuwe-maansgeleenthede) en sabbatsonderhouding. Hulle 'nederigheid' verwys dan hier na hulle beklemtoning van vasgebruike en ander rigoristiese praktyke om die liggaam te dissiplineer - waarby die vraag natuurlik ontstaan waartoe dit alles gedien het, wat dus daarmee beoog is. Die antwoord hierop moet in die oorblywende elemente van die bedreiging se karakterisering gesoek word.

Voorop staan die verwysing in 2: 19 dat dit hier gaan om mense wat nie 'vashou aan die Hoof nie'. Hierdie uitdrukking word gewoonlik gelees asof dit tiperend sou wees van 'n groep binne die gemeente wat 
die band aan die Seun van God nie meer belangrik ag nie, of andersins, asof hulle deur hulle verering van die engele, wat voorts ongegrond gekoppel word aan 'n verering van die owerhede en magte, wat dan ook hiervolgens, ewe ongegrond, die verering van tà stoicheîa toû kósmou sou behels, die band met Christus outomaties verbreek het.

Kratéo word hier uiteraard figuurlik aangewend om die verbondenheid met die Hoof aan te dui. Die negasie hoef egter nie te beteken dat ' $n$ bestaande verhouding prysgegee is nie; dit sou, binne die figuurlike konteks, ewe goed kon slaan op 'n nie-bestaande verhouding. Wat die uitdrukking hier wil aandui, is die kontras tussen die lesers en die groep wat vir hulle 'n bedreiging inhou. Die skrywer wil dan sê: Anders as julle wat lede van God se volk is omdat julle in verhouding tot die Seun van God getree het en dus tot die liggaam van Christus behoort, anders as julle wat aan Christus as Hoof van sy kerk verbonde is, vashou, staan hierdie mense los van Hom, is hulle nie aan Hom verbonde nie, hou húlle nie aan Hom vas nie.

'n Volgende eienskap teken hulle gewaande wysheid as bestaande en ethelothfrēskía (2: 23). Alhoewel sommige hierdie woord verstaan in die sin van eiewillige godsdiens (so bv ook die ou Afrikaanse Vertaling, vgl die NAV: selfgemaakte godsdiens), lê die klem hier waarskynlik eerder op die gedagte van 'n selfopgelegde diens (vgl Louw \& Nida 1988a: 533; Liddel, Scott \& Jones 1940: 479: 'self-chosen service', vgl ethelodouleia: 'voluntary subjection').

In plaas daarvan om hierdie selfopgelegde diens met die 'verering van engele' gelyk te stel (vgl Bratcher \& Nida 1977: 72), en dan nog hierdie laaste aangeleentheid soos dikwels gebèur (vgl hierbo), verder met die diens aan owerhede en magte en aan die elemente van die wêreld, te vereenselwig, lyk dit binne die raamwerk van die ondersoekgeskiedenis gebode om ook hierdie selfopgelegde diens as 'n aanduiding van asketiese praktyke te verstaan. Die selfopgelegde godsdiens verwys dan na die rigoristiese selfdissipline wat as 'n vrywillige godsdienstige praktyk deur die groep aanvaar is ter bereiking van die besondere doel waarin hulle geinteresseerd is. Die vraag wat nog onbeantwoord bly, is dié na hierdie doelstelling.

Sonder dat hierdie vraag hier volledig behandel kan word, lyk dit my tog dat die beste antwoord hierop te vinde is in die rigting van die Joodse mistiek met sy gerigtheid op die hemelreis van die siel, na verlange om die troon van God te sien, en met die engele (thrēskeía tōn angéllōn $=$ die diens deur engele verrig, vgl hierbo) te deel in die 
hemelse erediens (Francis 1975a; 1975b; Bandstra 1974; Evans 1982; vgl ook Carr 1973).

Een van die vroegste verwysings na 'n mistieke hemelreis en die waarneming van en deelname saam met die engele aan die hemelse erediens, asook die vermelding van die voorafgaande voorbereidingstyd, is voor hande in die Apokalips van Abraham (vgl Charlesworth 1983: 681-705; vgl ook 1 Hen 14: 8-15: 4; 71: 1-11). Abraham kom tot die insig dat afgodsdiens dwaasheid is en begin vra na die ware God wat alles geskape het (1-7). Hy moet vir veertig dae vas en homself dissiplineer $(9: 7 ; 12: 1-2)$. Nadat hy die vereiste offer gebring het moet hy die teenstand van Azazel oorkom (13:4-14) met die resitering van woorde wat die engel Jaoel hom geleer het (14: 8). Hierna word hulle in die vlamme van die offervuur na omhoog gevoer (15: 3-5). Te midde van die geweldige klank van 'n groot stem, val die engel neer in aanbidding en moet ook Abraham aanbid (17: 1-5). Hiermee gaan gepaard die resitering van ' $n$ lied wat die engel hom geleer het: '... I ... bowed down, and I recited the song which he had taught me. And he said, "Recite without ceasing". And I recited, and he himself recited the song' (17: 5-7). Die lied self word in 17: $8-21$ weergegee en is ' $n$ goeie voorbeeld van die oor-en-oor herhaalde inkanterings wat volgens Scholem (1961: 57) gedien het om die weg na omhoog te begelei: '... their recitation serves to induce a state of ecstasy and accompanies the traveler on his journey through the gates'. Hierna sien Abraham die troonwa (merkabah), en die engele in hulle diens (18vv). Dié ervaring beleef hy as deur God na omhoog opgelei te gewees het $(20: 7 ; 28: 2)-$ die teenhanger van die verwysing in Kolossense 2: 18 wat praat van dit wat die visioenêr gesien het toe hy ingegaan het.

Die volgende aanhaling uit Scholem (1961: 43-44) vat die saak waarom dit hier gaan besonder duidelik saam:

What was the central theme of these oldest of mystical doctrines within the framework of Judaism? No doubts are possible on this point: the earliest Jewish mysticism is throne-mysticism. Its essence is not absorbed contemplation of God's true nature, but perception of His appearance on the throne, as described by Ezekiel, and cognition of the mysteries of the celestial throneworld. The throne-world is to the Jewish mystic what the pleroma, the "fullness", the bright sphere of divinity with its potencies, aeons, archons and dominions is to the Hellenistic and early Christian mystics of the period who appear in the history of 
religion under the names of Gnostics and Hermetics. The Jewish mystic, though guided by motives similar to theirs, nevertheless expresses his vision in terms of his own religious background. God's pre-existing throne, which embodies and exemplifies all forms of creation, is at once the goal and the theme of his mystical vision. From the fourteenth chapter of the Ethiopic Book of Enoch, which contains the oldest description of the throne in the whole of this literature, a long succession of mystical documents of the most varied character leads to the ecstatic descriptions of the throneworld in the tracts of the Merkabah visionaries...

In die lig van die bogaande kan die verwysing na die owerhede en magte $(2: 10,15)$ eweneens verstaan word teen die agtergrond van hierdie mistieke beskouing wat in hierdie opsig die algemene Joodse opvatting oor die geestelike wêreld deel: Dit gaan om bose magte wat invloed uitoefen op die mens se lewe.

Die laaste eienskap van hierdie groep mense waaraan hier aandag gegee moet word naamlik, hulle onregmatige selfvoldaanheid (2: 18 eikẽ fusioúmenos hupò tồ noòs tes sarkòs autôu), mag ons help om die situasie te rekonstrueer waarin dit nodig geword het om hierdie brief te skryf. Dat die gemeente in 'n sendingsituasie verkeer het, is vanselfsprekend. Tog het die skrywer dit nodig gevind om in hierdie brief spesiaal daarna te verwys in 4: 5 - en sofía peripateite pròs toûs éxō tòn kairòn exagorazómenoi. Hierteenoor het die opvattings van die groep waarteen die gemeente gewaarsku word en wat self tot die buitestaanders behoort, slegs 'n skyn van wysheid. Waarskynlik het die situasie waarin die brief tot stand gekom het juis hiermee te doen. In die uitvoering van die gemeente se sendingopdrag stuit hulle teen 'n Joodse groep met ' $n$ mistieke belangstelling en godsdienstige praktyk. Vir hierdie mense is die evangelieboodskap van die Gesalfde se heilswerk nie aanvaarbaar, of minstens nie genoegsaam nie: Hulle wil self tydens hulle aardse lewe die hemelreis onderneem om die troon te sien en die hemelse erediens te beleef en terug te keer met dié kennis om dit dan in hulle godsdiens toe te pas. En nou kan dié wat die mistieke ervaring al beleef het, wat die visioen van God op sy troon gesien het, en wat die engele hoor sing het, en met hulle in dié verering van God gedeel het, vir die sendende gemeente sê: 'Ons was al daar, ons het dit alles gesien, ons het die tradisies van hierdie soort belewenisse; julle kan ons niks vertel nie!' Teen hierdie soort agter- 
grond en in die lig van hierdie soort reaksie, word die tipering van die groep as mense wat onregmatig selfvoldaan is, verstaanbaar.

\subsubsection{Die Christelike belydenis en die bedreiging}

Wil ons nou die funksie van die belydenisaspekte in 1: 13-23 ten opsigte van die bedreiging probeer bepaal, blyk die volgende:

- Die gemeente moet nie in verwarring kom oor die hooghartige aansprake van die groep mistici nie, want God het hulle gered deur die heilswerk van sy Seun. Hulle is verlos; hulle sonde is vergewe. Hulle moet nie begin wonder of die mistieke hemelreis tog nie vir hulle voordeel sal inhou nie: Die praatjies daaroor is 'n nuttelose dwaling.

- Die alles oorheersende belang en rol van die Gesalfde, die beeld van God, dien om elke gedagte aan iets ekstras vir die verwerwing van die heil van God buite perke te stel. Alle geskapene staan onder Hom sodat Hy ook Heerser is oor die owerhede en magte. Verbonde aan Hom as Hoof, het die gelowiges die volle heil van God deelagtig geword, behoef hulle buite Hom niks nie, en het hulle ook van geen ander instansie enigiets te vrees nie. Ten diepste bly die mistici aan die aardse sfeer verbonde: In hulle aardse lewe wil hulle die hemel betree deur aardse tegnieke wat moet help om die aardse lewe tydelik vir 'n besoek aan die hemel te verlaat. Wie aan die Gesalfde verbonde is en met Hom gesterf het, leef nie meer in die aardse bedeling nie. Hy is saam met die Gesalfde opgewek sodat sy lewe nie meer beheers word deur die elemente wat hierdie aardse bestaan verteenwoordig nie. Hulle is klaar met die Gesalfde in die hemel, hoef dus nie deur aardse tegnieke te strewe om daar besoek te gaan aflê nie. Omdat hulle lewe nou beheers word deur die suiwer geestelike sfeer daarbo, moet juis hulle aardse bestaan daardeur gekenmerk word dat hulle van bo beheers word (2: 20-3: 4).

'n Oplossing gesoek in die rigting hier aangedui, kan moontlik help om twee eienaardighede in die teks van Kolossense te verklaar, te wete die presentiese eskatologie en die gebrek aan verwysings na die Heilige Gees (vgl vir laasgenoemde Schweizer 1973; vgl ook Kehl 1967: 120-125; Bandstra 1975). Wat die eerste aangaan, kan met 'n groot mate van sekerheid gestel word dat die presentiese eskatologie daarop gemik is om die aansprake van mistici oor hemelreise in hierdie liggaamlike bedeling teen te werk deur te beklemtoon dat vir die gelowiges die heilsbedeling reeds ingegaan het. Die ontbreking van werklike verwy- 
sings na die Heilige Gees sou miskien verklaar kon word as versigtigheid aan die kant van die skrywer om nie die ekstatiese entoesiasme wat by die mistiek voorgekom het, in die gemoed van die gemeentelede met verwysings na die Heilige Gees te onderskraag nie.

\section{Literatuurverwysings}

BANDSTRA, AJ 1974. Did the Colossian errorists need a mediator? in Longenecker, RN \& Tenney, MC (eds) 1974, New dimensions in New Testament study, 329-343. Grand Rapids: Zondervan.

BANDSTRA, A] 1975. Pleroma as Pneuma in Colossians, in Berkouwer, GC, Popma, SJ, Ridderbos, HN et al, Ad interim: Opstellen over Eschatologie, apocalyptiek en ethiek aangeboden aan Prof Dr R Schippers, 96-102. Kampen: Kok.

BLINZLER, J 1963. Lexikalisches zu dem Terminus tà stoicheia toû kósmou bei Paulus. AnalBibl 17-18, 429-443.

BORNKAMM, G 1975. The heresy of Colossians, in Francis \& Meeks 1975: 123-145.

BRATCHER, RG \& NIDA EA 1977. A translator's handbook on Paul's letters to the Colossians and to Philemon. Stuttgart: United Bible Societies.

BRUCE, FF 1984. The Colossian heresy. BS 141, 195-208.

CARR, W 1973. Two notes on Colossians. JTS 24, 492-500.

CHARLESWORTH, JH (ed) 1983. The Old Testament Pseudepigrapha. New York: Doubleday.

DIBELIUS, M 1975. The Isis initiation in Apuleius and related initiatory rites, in Francis \& Meeks 1975: 61-121.

ERNST, J 1974. Die Briefe an die Philipper, an Philemon, an die Kolosser, an die Epheser. Regensburg: Pustet.

EVANS, CA 1982. The Colossian mystics. Bib 63, 188-205.

EWALD, P 1910. Die Briefe des Paulus an die Epheser, Kolosser und Philemon. 2. Aufl. Leipzig: Deichert.

FOERSTER, W 1966. Die Irrlehrer des Kolosserbriefes, in Beek, MA, De Boer, PAH, Brongers, HA et al. Studia Biblica et Semitica Theodoro Christiano Vriezen qui munere professoris theologiae per $X X V$ annos functus est, ab amicis, collegis, discipulis dedicata, 71-80. Wageningen: Veenman.

FRANCIS, FO 1975a. Humility and angelic worship in Col 2:18, in Francis \& Meeks 1975: 163-195.

FRANCIS, FO 1975b. The background of embateuein ( $\mathrm{Col} 2: 18)$ in legal papyri and oracle inscriptions, in Francis \& Meeks 1975: 197-207.

FRANCIS, FO \& MEEKS, WA (eds) 1975. Conflict at Colossae: $A$ problem in the interpretation of Early Christianity illustrated by selected modern studies. Rev ed. Missoula: Scholars Press.

GNILKA, J 1980. Der Kolosserbrief. Freiburg: Herder.

GROENEWALD, EP 1944. Die dwaalleer te Kolosse. Woord en Waarheid 1, no 1, 21-25; 1 , no 2, 5-15.

GUNTHER, JJ 1973. St. Paul's opponents and their background: A study of apocalyptic and Jewish sectarian teachings. Leiden: Brill.

HOOKER, MD 1973. Were there false teachers in Colossae? in Lindars \& Smalley 1973: 315-331.

KEHL, N 1967. Der Christushymnus im Kolosserbrief: Eine motivgeschichtliche Untersuchung zu Kol 1, 12-20. Stuttgart: Katholisches Bibelwerk.

KERN, W 1974. Die antizipierte Entideologisierung oder die "Weltelemente" des Galaterund Kolosserbriefes Heute. ZKT 96, 185-216. 
LÄHNEMANN, J 1971. Der Kolosserbrief: Komposition, Situation und Argumentation. Gütersloh: Mohn.

LIDDEL, HG, SCOTT, R \& JONES, HS (eds) 1940. A Greek-English lexicon. 9th ed. Oxford: Clarendon.

LIGHTFOOT, JB [1879] 1961. Saint Paul's epistles to the Colossians and to Philemon with introduction, notes and dissertations. Rev ed. Grand Rapids: Zondervan.

LINDARS, B \& SMALLEY, SS (eds) 1973. Christ and the Spirit in the New Testament: Studies in honor of Charles Francis Digby Moule. Cambridge: Cambridge University Press.

LOHSE, E 1977. Die Briefe an die Kolosser und an Philemon. 2. Aufl. Göttingen: Vandenhoeck.

LOUW, JP \& NIDA, EA (eds) 1988a. Greek-English lexicon of the New Testament based on Semantic domains, Volume 1: Introduction and domains. New York: United Bible Societies.

LOUW, JP \& NIDA, EA (eds) 1988b. Greek-English lexicon of the New Testament based on Semantic domains, Volume 2: Indices. New York: United Bible Societies.

LYONNET, S 1975. Paul's adversaries in Colossae, in Francis \& Meeks 1975: 147-161.

METZGER, BM 1971. A textual commentary on the Greek New Testament. London: United Bible Societies.

MOYA, A 1984. The Colossian heresy in the light of some gnostic documents from Nag Hammadi. JTSA 48, 30-44

O'BRIEN, PT 1982. Colossians, Philemon. Waco: Word Books.

POKORNÝ, P 1987. Der Brief des Paulus an die Kolosser. Berlin: Evangelische Verlagsanstalt.

ROBERTS, JH 1986. Transitional techniques to the letter body in the corpus Paulinum, in Petzer, JH \& Hartin, PJ (eds) 1986, A South African perspective on the New Testament: Essays by South African New Testament scholars presented to Bruce Manning Metzger during his visit to South Africa in 1985, 185-201. Leiden: Brill.

ROBERTS, JH 1987. Filemon in diskussie: Enkele hoogtepunte in die stand van sake. Scriptura 21, 24-50.

ROBERTS, JH 1988. Belydenisuitsprake as Pauliniese briefoorgange. HTS 44, 81-97.

SCHENK, W 1987. Der Kolosserbrief in der neueren Forschung (1945-1985), in ANRW 25, 3328-3364.

SCHOLEM, G 1971. sv Merkabah mysticism or ma'aseh merkavah. Encyclopedia /udaica $11,1386-1389$.

SCHOLEM, GG 1961. Major trends in Jewish mysticism. New York: Schocken.

SCHWEIZER, E 1973. Christus und die Geist im Kolosserbrief, in Lindars \& Smalley 1973: 297-314.

SCHWEIZER, E 1976. Zur neueren Forschung am Kolosserbrief (seit 1970), in Pfammatter, J \& Furger, F (Hrsg). Glaube und Geschichte: Zum 60. Geburtstag des Bischofs von Chur, Msgr Dr Johannes Vorderach, am 6 Mai 1976, 163-191. Zurich: Benziger.

STEWART, JS 1970. A first-century heresy and its modern counterpart. SJT 23, 420-436. WHITE, JL 1975. The form and function of the body of the Greek letter: A study of the letter-body in the non-literary papyri and in Paul the apostle. 2nd ed. Missoula: Scholars Press.

YATES, R 1986. Colossians and gnosis. JSNT 27, 49-68.

ZAHN, T 1906. Einleitung in das Neue Testament. 1. Band. 3. Aufl. Leipzig: Deichert.

ZERWICK, M \& GROSVENOR, M 1979. A grammatical analysis of the Greek New Testament, Volume 2: Epistles-Apocalypse. Rome: Biblical Institute Press. 